\title{
Modification of Cary-Blair Transport Medium for Pasteurella multocida and Mannheimia haemolytica
}

\author{
G. TEFERA, J. SMOLA
}

Department of Microbiology and Immunology, Faculty of Veterinary Medicine, University of Veterinary and Pharmaceutical Sciences, Brno

Received January 24, 2002

Accepted June 19, 2002

\section{Abstract}

Tefera G., J. Smola: Modification of Cary-Blair Transport Medium for Pasteurella multocida and Mannheimia haemolytica. Acta Vet. Brno 2002, 71: 229-233.

The aim of this study was to evaluate the effectiveness of Cary-Blair, Amies and modified Cary-Blair medium for transport of $P$. multocida and $M$. haemolytica strains. Pure cultures of nine strains of $P$. multocida, representing all subspecies, and nine strains of $M$. haemolytica were inoculated into the media to test their convenience. The ability of the strains to survive in each of these media was determined periodically (on days 5, 10, 15, 20, 30, 45, 60, 75, 90, respectively) at different temperatures (alternatively at $21^{\circ} \mathrm{C}$ and $4{ }^{\circ} \mathrm{C}$ ) and at room temperature (constantly at $21^{\circ} \mathrm{C}$ ). Comparing with the Cary-Blair and Amies medium, P. multocida strains survived for 45 days and $M$. haemolytica strains for 30 days in modified Cary-Blair medium. Based on the present observation, Cary-Blair medium modified by the addition of horse blood serum is the most effective of those tested media for the transport of P. multocida and $M$. haemolytica strains.

Transport medium, P. multocida, M. haemolytica

A transport medium convenient for Pasteurella and Mannheimia has not been well investigated and established. For the first time Percy et al. (1984) used Cary-Blair medium as the transport medium for a survey of serotypes of $P$. multocida, and suggested the use of this medium to transport respiratory pathogens. Furthermore, Shimoda et al. (1991) analyzed the stability of pathogenic bacteria from laboratory animals in various transport media and showed that with phosphate-buffered saline (PBS) and PBS it was difficult to maintain Pasteurella strains at various temperatures $\left(37{ }^{\circ} \mathrm{C}, 24{ }^{\circ} \mathrm{C}\right.$ and $\left.4{ }^{\circ} \mathrm{C}\right)$. Recently, by comparing eight transport media, Kaw a moto et al. (1997) showed that Cary-Blair medium and Leibovitz medium No. 15 are the effective media to transport $P$. multocida strains. During this investigation, it was indicated that Cary-Blair medium is superior for the transport of strains of Pasteurella spp. isolated from animals and humans.

Based on this finding, the present study was carried out to evaluate Cary-Blair, Amies and modified Cary-Blair medium for safe transport of $P$. multocida and M. haemolytica

\section{Materials and Methods}

Bacterial strains

A total of eighteen strains of $P$. multocida and $M$. haemolytica were used in this study. Two of them were type strains and eight of them were reference strains. Both type and reference strains were obtained from CCM (Czech Collection of Microorganisms). The remaining eight strains, which were identified using RapiD 20 E (bioMérieux, France), were isolated from fatal infectious cases of cattle, pigs and poultry (Table 1).

Swabs

Synthetic-tipped individually wrapped cotton swabs sterilized by ionizing radiation (Copanitalia, Italy) were used to collect field samples and pure cultures of P. multocida and M. haemolytica.

Address for correspondence:

Dr. Genene Tefera

Department of Microbiology and Immunology

University of Veterinary and Pharmaceutical Sciences

Palackého 1/3 Brno, Czech Republic
Phone: +420 541562282

Fax: +420 541212646

http:/www.vfu.cz/acta-vet/actavet.htm 
Table 1

Type, reference and field strains of $P$. multocida and M. haemolytica used for this study

\begin{tabular}{|c|c|c|}
\hline Species & Origin & Strains \\
\hline P. multocida & Bovine & type (CCM 5903) \\
\hline P. multocida & Bovine & reference (CCM 6081) \\
\hline P. multocida ssp. septica & Bovine & reference (CCM 4730) \\
\hline P. multocida ssp. gallicida & Bovine & reference (CCM 4731) \\
\hline P. multocida ssp. multocida & Bovine & reference (CCM 5419) \\
\hline P. multocida & Porcine & field (8891) \\
\hline P. multocida & Porcine & field (8967) \\
\hline P. multocida & Avian & field (9506) \\
\hline P. multocida & Bovine & field (10338) \\
\hline M. haemolytica & Bovine & type (CCM 5141) \\
\hline M. haemolytica & Bovine & reference (CCM 6169) \\
\hline M. haemolytica & Ovine & reference (CCM 6170) \\
\hline M. haemolytica & Ovine & reference (CCM 6174) \\
\hline M. haemolytica & Ovine & reference (CCM 6176) \\
\hline M. haemolytica & Bovine & field (9122) \\
\hline M. haemolytica & Bovine & field (10339) \\
\hline M. haemolytica & Bovine & field (10517) \\
\hline M. haemolytica & Bovine & field (10518) \\
\hline
\end{tabular}

Bacteriological Media

Transport media

Cary-Blair transport medium (CM519, Oxoid) and Amies transport medium (CM425, Oxoid)

The media were prepared according to the manufacturer's instructions (Oxoid) by distributing $1.5 \mathrm{ml}$ into Nunc Cryotubes (Denmark) and sterilized by immersing in free-steam for 15 minutes. The tubes were allowed to cool and tightened to prevent water loss.

Modified Cary-Blair medium

The medium was prepared by adding $5 \% \mathrm{v} / \mathrm{v}$ of sterile horse blood serum to Cary-Blair medium (Oxoid) at $50{ }^{\circ} \mathrm{C}$ and distributing $1.5 \mathrm{ml}$ into tubes. The tubes were cooled and tightened to prevent water loss.

Culture medium

Sheep blood agar was prepared according to the manufacturer by adding sheep blood ( $5 \% \mathrm{v} / \mathrm{v})$ to the Columbia blood agar base (CM351, Oxoid).

Inoculation, storage and survival checking

All type, reference and field strains of $P$. multocida and $M$. haemolytica were routinely cultured on sheep blood agar at $37^{\circ} \mathrm{C}$. Four colonies of $P$. multocida and $M$. haemolytica, taken from fresh overnight cultures of each strain, were transferred using sterile loops to Cary-Blair medium, modified Cary-Blair medium and Amies transport medium. These media were stored at different temperatures (alternatively at $21{ }^{\circ} \mathrm{C}$ and $4{ }^{\circ} \mathrm{C}$ ) and at room temperature (constantly at $21^{\circ} \mathrm{C}$ ) for a period of 45-90 days. The strains were periodically recultivated on sheep blood agar using sterile loops by forming 5 overlapping segments to check their survival ability based on the quantity of bacterial cells. The plates were incubated aerobically at $37^{\circ} \mathrm{C}$ for $24 \mathrm{~h}$.

Reading of results

Survival ability of $P$. multocida and $M$. haemolytica strains was checked at periodical intervals of days (i.e. on day 5, 10, 15, 20,30, 45 (experiment 1, 2,3), 60 (Experiment 2, 3), 75 and 90 (Experiment 4)). The evaluation was conducted visually according to the growth of each strain on sheep blood agar plates (Claus 1981). The presence of growth of each strain on streaked segments of blood agar was classified as positive and its absence as negative.

Design of experiment

The ability of $P$. multocida and M. haemolytica strains to survive on the tested transport media was observed in four experimental stages. All eighteen strains were inoculated in Cary-Blair medium and their survival ability was observed for 45 days at different temperatures (alternatively at $21^{\circ} \mathrm{C}$ and $4{ }^{\circ} \mathrm{C}$ ) (Experiment 1 ). These media were stored alternatively at $21{ }^{\circ} \mathrm{C}$ and $4{ }^{\circ} \mathrm{C}$ every day in order to simulate with the conditions in which the specimens are collected and transported. On the other hand, the same strains of $P$. multocida and M. haemolytica 
were observed for 60 days in Cary-Blair (Experiment 2) and Amies medium (Experiment 3) at room temperature (constantly at $21^{\circ} \mathrm{C}$ ), and they were observed for 90 days in the modified Cary-Blair medium at room temperature (Experiment 4).

\section{Results}

In the first experiment, all M. haemolytica strains survived only until day 5 , whereas all P. multocida strains survived until day 15 (Table 2). In the second experiment, 8 strains of $M$. haemolytica survived until day 10 , and 4 of them until day 15 , whereas all $P$. multocida strains showed their survival ability until day 15 , and 4 of them until day 30 (Table 3 ). In the third experiment, all $M$. haemolytica survived until day 5, and all P. multocida strains survived until day 10 (Table 3). In the fourth experiment, 8 strains of $M$. haemolytica survived until day 30, and 4 of them until day 45, whereas all $P$. multocida strains survived until day 45 , and 4 of them survived until day 75 (Table 4). Furthermore, type and reference strains showed very typical characteristics (i.e. decreased survival ability comparing with field strains (Table 3, 4)).

Table 2

The ability of $P$. multocida and M. haemolytica strains to survive in Cary-Blair medium at different temperatures (alternatively at $21^{\circ} \mathrm{C}$ and $4{ }^{\circ} \mathrm{C}$ )

\begin{tabular}{|l|l|c|c|c|c|c|c|c|}
\hline \multirow{2}{*}{ Species } & \multirow{2}{*}{ Strains } & \multirow{2}{*}{$\begin{array}{c}\text { No of } \\
\text { strains }\end{array}$} & \multicolumn{7}{|c|}{ Day of observation } \\
\cline { 5 - 9 } & & & 5 & 10 & 15 & 20 & 30 & 45 \\
\hline & type & $\mathbf{1}$ & $+(1)$ & $+(1)$ & $+(1)$ & - & - & - \\
\hline P. multocida & reference & 4 & $+(4)$ & $+(4)$ & $+(4)$ & - & - & - \\
\hline & field & 4 & $+(4)$ & $+(4)$ & $+(4)$ & - & - & - \\
\hline & type & 1 & $+(1)$ & - & - & - & - & - \\
\hline M. haemolytica & reference & 4 & $+(4)$ & - & - & - & - & - \\
\hline & field & 4 & $+(4)$ & - & - & - & - & - \\
\hline
\end{tabular}

Table 3

The ability of $P$. multocida and $M$. haemolytica strains to survive in Cary-Blair and Amies transport medium at room temperature $\left(21^{\circ} \mathrm{C}\right)$

\begin{tabular}{|c|c|c|c|c|c|c|c|c|c|c|}
\hline \multirow{2}{*}{ Medium } & \multirow{2}{*}{ Species } & \multirow{2}{*}{ Strains } & \multirow{2}{*}{$\begin{array}{l}\text { No of } \\
\text { strains }\end{array}$} & \multicolumn{7}{|c|}{ Day of observation } \\
\hline & & & & 5 & 10 & 15 & 20 & 30 & 45 & 60 \\
\hline \multirow{6}{*}{ Cary-Blair } & \multirow{3}{*}{ P. multocida } & type & 1 & $+(1)$ & $+(1)$ & $+(1)$ & - & - & & - \\
\hline & & reference & 4 & $+(4)$ & $+(4)$ & $+(4)$ & - & - & - & - \\
\hline & & field & 4 & $+(4)$ & $+(4)$ & $+(4)$ & $+(4)$ & $+(4)$ & - & - \\
\hline & \multirow{3}{*}{ M. haemolytica } & type & 1 & $+(1)$ & - & - & - & - & - & - \\
\hline & & reference & 4 & $+(4)$ & $+(4)$ & - & - & - & - & - \\
\hline & & field & 4 & $+(4)$ & $+(4)$ & $+(4)$ & - & - & - & - \\
\hline \multirow{6}{*}{ Amies } & \multirow{3}{*}{ P. multocida } & type & 1 & $+(1)$ & $+(1)$ & - & - & - & - & - \\
\hline & & reference & 4 & $+(4)$ & $+(4)$ & - & - & - & - & - \\
\hline & & field & 4 & $+(4)$ & $+(4)$ & - & - & - & - & - \\
\hline & \multirow{3}{*}{ M. haemolytica } & type & 1 & $+(1)$ & - & - & - & - & - & - \\
\hline & & reference & 4 & $+(4)$ & - & - & - & - & - & - \\
\hline & & field & 4 & $+(4)$ & - & - & - & - & - & - \\
\hline
\end{tabular}


Table 4

The ability of $P$. multocida and $M$. haemolytica strains to survive in modified Cary-Blair medium at room temperature $\left(21^{\circ} \mathrm{C}\right)$

\begin{tabular}{|c|c|c|c|c|c|c|c|c|c|c|c|}
\hline \multirow{2}{*}{ Species } & \multirow{2}{*}{ Strains } & \multirow{2}{*}{$\begin{array}{l}\text { No of } \\
\text { strains }\end{array}$} & \multicolumn{9}{|c|}{ Day of observation } \\
\hline & & & 5 & 10 & 15 & 20 & 30 & 45 & 60 & 75 & 90 \\
\hline \multirow{3}{*}{ P. multocida } & type & 1 & $+(1)$ & $+(1)$ & $+(1)$ & $+(1)$ & $+(1)$ & $+(1)$ & - & - & - \\
\hline & reference & 4 & $+(4)$ & $+(4)$ & $+(4)$ & $+(4)$ & $+(4)$ & $+(4)$ & - & - & - \\
\hline & field & 4 & $+(4)$ & $+(4)$ & $+(4)$ & $+(4)$ & $+(4)$ & $+(4)$ & $+(4)$ & $+(4)$ & - \\
\hline \multirow{3}{*}{ M. haemolytica } & type & 1 & $+(1)$ & $+(1)$ & $+(1)$ & $+(1)$ & - & - & - & - & - \\
\hline & reference & 4 & $+(4)$ & $+(4)$ & $+(4)$ & $+(4)$ & $+(4)$ & - & - & - & - \\
\hline & field & 4 & $+(4)$ & $+(4)$ & $+(4)$ & $+(4)$ & $+(4)$ & $+(4)$ & - & - & - \\
\hline
\end{tabular}

\section{Discussion}

Little work has been done on transporting P. multocida and M. haemolytica specimens from domestic animals. Charter et al. (1989) reported the effects of storage in the transport media and storage temperature on these bacterial species. They showed that the recovery rate of the strains decreased to $50 \%$ after $48 \mathrm{~h}$ when the specimens kept in the medium at $10{ }^{\circ} \mathrm{C}$. Furthermore, they confirmed the very poor survival ability of both species at low temperature. In contrast, the stability of the strains at room temperature was greater in CaryBlair medium. Similarly, Ka w a moto et al. (1997) confirmed that Cary-Blair medium was superior to Stuart medium, Schaedler broth, thioglycollate broth, thioglycollate broth with $0.5 \%$ agar, Leibovitz medium No.15, and commercial systems, which enable the survival of $P$. multocida for more than 14 days at room temperature. However, they evaluated only $P$. multocida strains isolated from rabbits. It was therefore important to find the best medium for transporting specimens containing $P$. multocida and $M$. haemolytica from field to veterinary laboratories. In our study, both $P$. multocida and $M$. haemolytica strains, isolated from different animal species, were analyzed. The most popular transport media (i.e. CaryBlair and Amies) commonly used for general purpose, were tested in comparison with modified Cary-Blair medium. Our present study showed that the survival ability of the strains was longer in Cary-Blair medium at room temperature $\left(21{ }^{\circ} \mathrm{C}\right)$ than at different temperatures (alternatively at $21{ }^{\circ} \mathrm{C}$ and $4{ }^{\circ} \mathrm{C}$ ). In contrast to other bacterial species, $P$. multocida and $M$. haemolytica die shortly after being stored or transported at low temperatures. For this reason, they are not surviving longer when they are transported at $4{ }^{\circ} \mathrm{C}$. The optimal temperature for both bacterial species is the room temperature (Carter 1983). For these reasons, they showed better and longer survival ability at room temperature in modified Cary-Blair medium. The shortest survival ability was observed in type strains of $M$. haemolytica in all the used media. From this experience, the authors of the study recommend the use of type strain (CCM 5141) to test the most convenient transport medium for bacterial species of the family Pasteurellaceae. Also comparing with the Amies medium, modified Cary-Blair medium is better in transporting of both bacterial species. On the other hand, strains of $P$. multocida survived for longer time than strains of $M$. haemolytica in all media tested. This also shows the distinction between the two genera. Generally, the advantage of modified Cary-Blair medium is that it protects the strains against different agents such as possible toxic effects of compounds (Hubálek 1996). Also, the authors confirmed that using horse blood serum in a given concentration never allows overgrowth of bacterial colonies of. P. multocida and M. haemolytica in the medium. Furthermore, the authors used horse blood serum in order to minimize the probability of the presence of specific antibodies against $P$. multocida and M. haemolytica strains. 
In conclusion: compared with Cary-Blair and Amies transport medium, all P. multocida strains survived for 45 days and all M. haemolytica strains for 30 days in the modified CaryBlair medium. The results of this study showed that modified Cary-Blair medium is superior to the other media tested with regard to survival of P. multocida and M. haemolytica in pure cultures and field specimens isolated in the Czech Republic and Ethiopia. Based on these findings, we recommend the use of the modified Cary-Blair transport medium for $P$. multocida and M. haemolytica strains, as well as its use for other bacterial species of the family Pasteurellaceae.

\section{Cary-Blairovo transportní medium modifikované pro Pasteurella multocida a Mannheimia haemolytica}

Cílem studie bylo zhodnotit účinnost vybraných transportních médií (Ames, Cary-Blair a modifikovaný Cary Blair) pro kmeny $P$. multocida a $M$. haemolytica. K testování vhodnosti médií byly použity čisté kultury devíti kmenů $P$. multocida reprezentujících všechny poddruhy a devíti kmenů $M$. haemolytica, které byly očkovány do testovaných médií. Schopnost přežívat byla ověrována periodicky (5., 10., 15., 20., 30., 45., 60., 75. a 90. dne) přri různých teplotách $\left(21^{\circ} \mathrm{C} \mathrm{a} 4{ }^{\circ} \mathrm{C}\right)$ a při pokojové teplotě $\left(21^{\circ} \mathrm{C}\right)$. Ve srovnání s transportním médiem podle Amese a nebo Cary-Blaira, dosáhlo období přežívání v modifikovaném Cary-Blairově médiu 45 dnů v př́ípadě kmenů $P$. multocida a 30 dnů u kmenů $M$. haemolytica. Na základě tohoto pozorování bylo Cary-Blairovo medium modifikované koňským krevním sérem vyhodnoceno jako nejvhodnější z testovaných médií pro transport kmenů $P$. multocida a $M$. haemolytica.

\section{Acknowledgments}

We thank Mrs. Kovařová and Mrs. Hofírková for their technical assistance. Also thanks are extended to those who gave their help in various ways. This work was supported by grants from the Ministry of Education, Youth and Sports of the Czech Republic Nos. 161700001 and 161700002.

\section{References}

CARTER, GR 1983: The Genus Pasteurella. In Veterinary Bacteriology and Virology, IA Merchant and RA Parker (7th ed.), CBS India 24: 335-53

CHANTER, N, GOODWIN, RFW, RUTTER, JM 1989: Comparison of methods for sampling and isolation of toxigenic Pasteurella multocida from the nasal cavity of pigs. Res Vet Sci 47: $355-358$

CLAUS, D 1981: Enrichment, isolation and purification of bacteria. In training course on running and management of culture collections. CCM, Brno, pp. B1-6

HUBÁLEK, Z 1996: Cryopreservation of microorganisms at ultra-low temperatures. Academia, Praha, pp.70-72

KAWAMOTO, E, SAWADRA, T, MARUYAMA, T 1997: Evaluation of transport media for Pasteurella multocida isolates from rabbit nasal specimens. J Clin Microbiol 351: 1948-1951

PERRY, DH, PRESCOTT, JF, BHASIN, JL 1984: Characterization of Pasteurella multocida isolated from rabbits in Canada. Can J Comp Med 48: 162-165

SMIODA, K, MAEJIMA, K, KUHARA, T, NAKAGAWA, M 1991: Stability of pathogenic bacteria from laboratory animals in various transport media. Lab Anim 25: 228-231 